\title{
Teaching Video NeuroImages: Sustained clonus of the upper extremity
}

James E. Siegler, MD, and Xin Zhou, MD

Neurology ${ }^{\circledR}$ 2018;90:e1273. doi:10.1212/WNL.0000000000005266

An 80-year-old man with a history of renal transplant, on tacrolimus and prednisone, presented with confusion and fever $\left(38.3^{\circ} \mathrm{C}\right)$. Brain MRI demonstrated leptomeningeal enhancement, and lumbar puncture revealed a mixed pleocytosis with 533 white blood cells $/ \mu \mathrm{L}$ (45\% lymphocytes) and 950 red blood cells $/ \mu \mathrm{L}$. Varicella zoster was identified in the CSF by PCR. He exhibited diffuse hyperreflexia and clonus at the bilateral finger and wrist flexors within 72 hours of admission (video, links.lww.com/WNL/A323). Spasticity and clonus are pathologic upper motor neuron signs that can be observed early in the course of meningoencephalitis ${ }^{1}$ and other acute neurologic disorders. ${ }^{2}$

\section{Author contributions}

James E. Siegler: preparation of manuscript, study supervision. Xin Zhou: acquisition of data, critical revision of manuscript for important intellectual content.

\section{Study funding}

No targeted funding reported.

\section{Disclosure}

The authors report no disclosures relevant to the manuscript. Go to Neurology.org/ $\mathrm{N}$ for full disclosures.

\section{References}

1. McCabe K, Tyler K, Tanabe J. Diffusion-weighted MRI abnormalities as a clue to the diagnosis of herpes simplex encephalitis. Neurology 2003;61:1015-1016.

2. Wissel J, Schelosky LD, Scott J, Christe W, Faiss JH, Mueller J. Early development of spasticity following stroke: a prospective, observational trial. J Neurol 2010;257:1067-1072.

\author{
Correspondence \\ Dr. Siegler \\ james.siegler@uphs. \\ upenn.edu
}

\section{MORE ONLINE}

$\Theta$ Video

links.lww.com/WNL/A323

$\rightarrow$ Teaching slides

links.lww.com/WNL/A324 


\section{Neurology}

\section{Teaching Video NeuroImages: Sustained clonus of the upper extremity James E. Siegler and Xin Zhou \\ Neurology 2018;90; 1273 \\ DOI 10.1212/WNL.0000000000005266}

This information is current as of April 2, 2018

\section{Updated Information \& Services}

References

Subspecialty Collections

Permissions \& Licensing

Reprints including high resolution figures, can be found at: http://n.neurology.org/content/90/14/e1273.full

This article cites 2 articles, 1 of which you can access for free at: http://n.neurology.org/content/90/14/e1273.full\#ref-list-1

This article, along with others on similar topics, appears in the following collection(s):

Clinical neurology examination

http://n.neurology.org/cgi/collection/clinical_neurology_examination Encephalitis

http://n.neurology.org/cgi/collection/encephalitis

Information about reproducing this article in parts (figures,tables) or in its entirety can be found online at:

http://www.neurology.org/about/about_the_journal\#permissions

Information about ordering reprints can be found online:

http://n.neurology.org/subscribers/advertise

Neurology ${ }^{\circledR}$ is the official journal of the American Academy of Neurology. Published continuously since 1951, it is now a weekly with 48 issues per year. Copyright (O) 2018 American Academy of Neurology. All rights reserved. Print ISSN: 0028-3878. Online ISSN: 1526-632X.

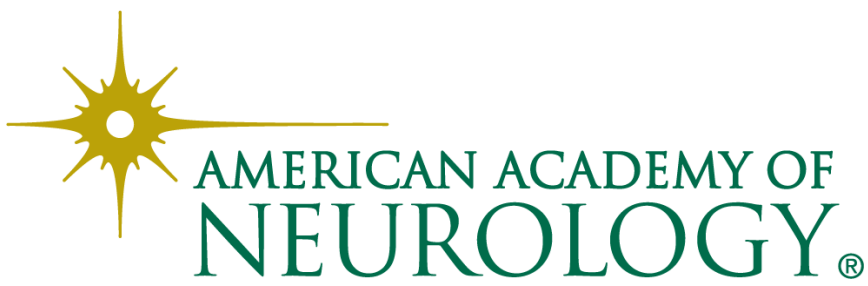

